\title{
KONDISI FISIK KIMIA AIR SUNGAI YANG BERMUARA DI TELUK SAWAIBU KABUPATEN MANOKWARI
}

\author{
Physical Chemical Condition of Rivers in Sawaibu Bay of Manokwari Regency \\ Muhammad Irwan $^{1}$, Alianto ${ }^{1}$, Yori Turu Toja ${ }^{1}$ \\ ${ }^{1}$ Jurusan Perikanan, FPIK UNIPA, Manokwari, 98314, Indonesia \\ *Korespondensi: ali.unipa@ymail.com
}

\begin{abstract}
ABSTRAK
Penelitian ini dilakukan di tiga sungai kecil (Momo, Sahara dan Konto) yang bermuara di Teluk Sawaibu Kabupaten Manokwari. Pengambilan sampel air untuk ketiga stasiun pengamatan dilakukan untuk pengukuran parameter fisik yaitu suhu, TDS, TSS dan kekeruhan, dan parameter kimia $\mathrm{pH}, \mathrm{DO}, \mathrm{COD}, \mathrm{BOD}$, Nitrat $\left(\mathrm{NO}_{3}\right)$, Fosfat $\left(\mathrm{PO}_{4}\right)$ dan Amonia. Tujuan dari penelitian ini adalah mengetahui kualitas fisik kimia air sungai dari lokasi penelitian, dan dibandingkan dengan baku mutu kualitas air berdasarkan Peraturan Pemerintah nomor 82 tahun 2001 tentang pengelolaan kualitas air dan pengendalian pencemaran air. Hasil pengukuran parameter fisik dan kimia adalah kisaran suhu dari tiga stasiun pengamatan berkisar antara $26,6-31^{\circ} \mathrm{C}$, kekeruhan berkisar 0,17-49,7 NTU. Padatan Terlarut Total (TDS) 134 - 317 mg/l. Padatan Tersuspensi Total $14-96$ mg/l. pH berkisar antara 6,69 - 7,78. DO (Dissolved Oxygen) 0,03-6,22 mg/l. COD (Chemical Oxygen Demand) <4,99 - 27,75 mg/l, BOD (Biochemical Oxygen Demand) 0,60 - 6,31 $\mathrm{mg} / \mathrm{l}$, Nitrat $\left(\mathrm{NO}_{3}-\mathrm{N}\right)$ 0,013-0,251 mg/l, Fosfat $\left(\mathrm{PO}_{4}\right)$ 0,013-0,243 mg/l dan Amonia $\left(\mathrm{NH}_{3}\right)$ 0,051-0,346 mg/l.
\end{abstract}

Kata Kunci: Padatan terlarut, padatan tersuspensi, sungai kecil, teluk Sawaibu.

\section{ABSTRACT}

This research was conducted in three small rivers (Momo, Sahara and Konto), which empties into the Gulf Sawaibu Manokwari District. Water sampling for the third observation station made for the measurement of physical parameters such as temperature, TDS, TSS and turbidity, and chemical parameters $\mathrm{pH}, \mathrm{DO}, \mathrm{COD}, \mathrm{BOD}$, nitrate $\left(\mathrm{NO}_{3}\right)$, phosphate $\left(\mathrm{PO}_{4}\right)$ and Ammonia. The purpose of this study was to determine the physical quality of the river water chemistry research sites, and compared with water quality standards based on Government Regulation No. 82 of 2001 on water quality management and water pollution control. The results of measurements of physical and chemical parameters is the temperature range from three observation stations ranged from 26.6 to 31

${ }^{\circ} \mathrm{C}$, ranges from 0.17 to 49.7 NTU turbidity. Total Dissolved Solids (TDS) $134-317 \mathrm{mg} /$ 1. Total Suspended Solids 14-96 mg / 1. pH ranges from 6.69 to 7.78. Dissolved Oxygen (DO) from 0.03 to $6.22 \mathrm{mg} / 1$. COD (Chemical Oxygen Demand) <4.99 to $27.75 \mathrm{mg} / \mathrm{l}$, BOD (Biochemical Oxygen Demand) from 0.60 to $6.31 \mathrm{mg} / 1$, nitrate (NO3-N) from 0.013 to $0.251 \mathrm{mg} / 1$, Phosphate ( PO 4) 0.013 to $0.243 \mathrm{mg} / 1$ and ammonia (NH3) from 0.051 to $0.346 \mathrm{mg} / \mathrm{l}$.

Key words: Disolved solids, Suspended solids, small river, Sawaibu bay.

\section{PENDAHULUAN}

Sungai merupakan sumber air per-mukaan yang memberikan manfaat kepada kehidupan manusia. Dari mata air sebagai awal mengalirnya air, melintasi bagian-ba-gian alur sungai hingga ke bagian hilir yang terjadi secara dinamis. Kedinamisan tersebut tergantung dari mu- 
sim, karakteristik alur sungai, dan pola hidup manusia disekitarnya. Kondisi ini menyebabkan baik kuantitas maupun kualitasnya akan mengalami perubahan-perubahan sesuai dengan perkembangan lingkungan sungai dan kehidupan manu-sia. Lingkungan perairan seperti daerah aliran sungai merupakan salah satu lingkungan yang paling sering terkena dampak pencemaran karena hampir semua limbah dibuang melalui sungai.

Jika limbah yang berupa bahan pen-cemar masuk ke suatu lokasi perairan sungai dapat menyebabkan perubahan. Perubahan dapat terjadi pada lingkungan perairan itu sendiri berupa faktor fisika dan kimia maupun pada organisme (biologis) yang hidup di lokasi tersebut (Suin, 1994). Dampak dari pencemaran tersebut dapat berupa perubahan struktur komunitas, penurunan biomassa atau produktifitas, perubahan tingkah laku, penu-runan laju pertumbuhan, terganggunya sistem reproduksi, hilangnya jenisjenis langka, perubahan daya tahan atas kemampuan hidup dan lain-lain (Zairion, 2003). Tujuan dari pe-nelitian ini adalah untuk menilai status kua-litas air pada tiga daerah aliran sungai yang bermuara di Teluk Sawaibu.

\section{METODE PENELITIAN}

\section{Lokasi dan Waktu Penelitian}

Penelitian dilaksanakan di tiga sungai kecil yang berada di tengah kota Manokwari (Gambar 1). Pengambilan contoh air dilaku-kan pada tiga stasiun dari bulan Mei - Juni 2014, stasiun I sungai Momo stasiun II su-ngai Sahara dan Stasiun III sungai Konto.
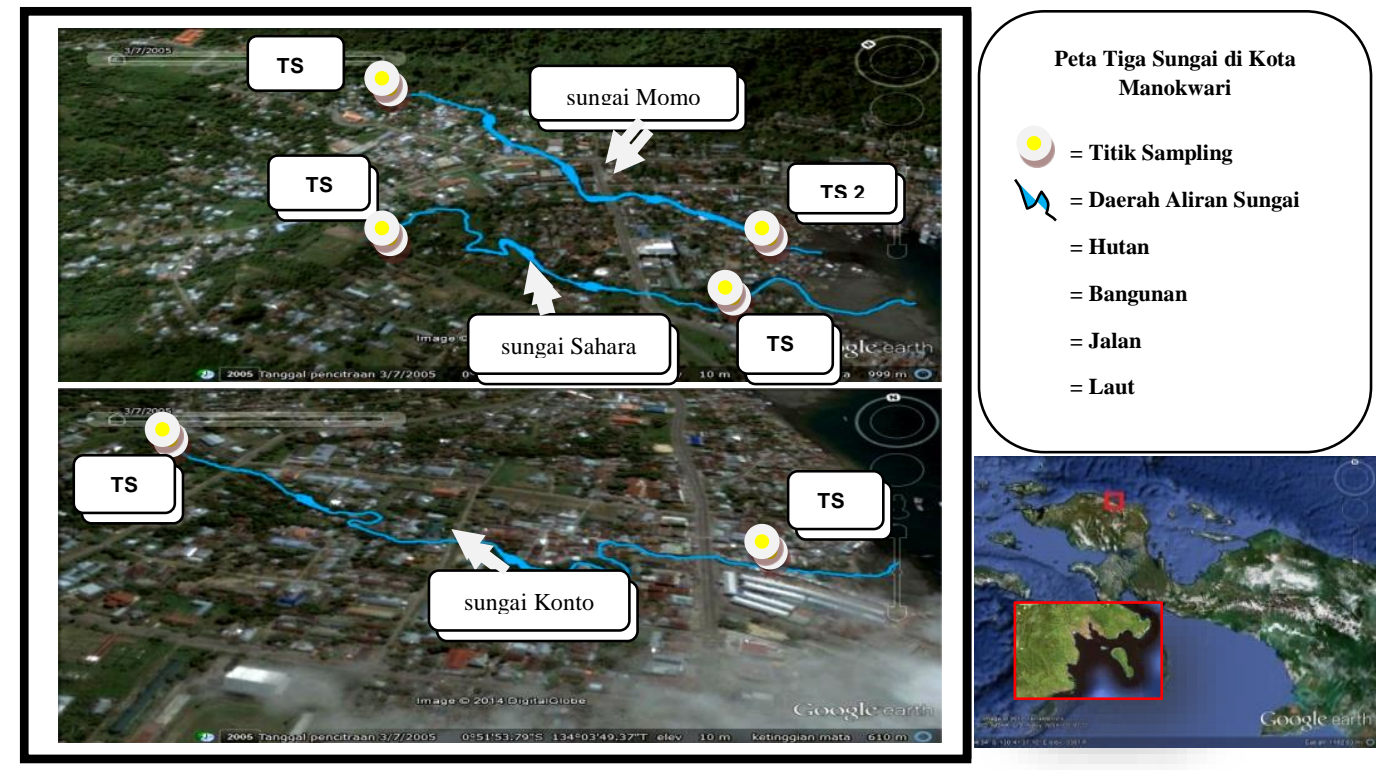

Gambar 1. Peta lokasi penelitian dan pengambilan contoh air di Sungai (Google)

Sungai Momo terletak di tengah pemu-kiman masyarakat yang memungkinkan se-mua buangan dari limbah rumah tangga, peternakan, perikanan dan industri rumah tangga langsung ke alirannya. Terdapat pemu-kiman dan ternak babi, budidaya perikanan, industri rumah tangga seperti pembuatan tahu, serta usaha pencucian motor juga buangan dari pertokoan. Sungai Sahara adalah salah satu aliran sungai yang terletak di daerah kota Manokwari yang langsung berhubungan dengan aktivitas masyarakat. Di bantaran sungai sahara ini terdapat pemukiman, kebun masyarakat, peternakan, dan di bagian hilir terdapat pertokoan serta bengkel motor. Sungai Konto secara kasat mata sudah tercemar terlihat dari warna dan baunya, yang bermuara di dekat pasar sentral Manokwari. Titik Koordinat Tiap Stasiun untuk lokasi penelitian adalah: Stasiun I : Hulu $\left({\mathrm{S} 00^{\circ}}^{\circ}\right.$ 
50'52,7' dan E $134^{0} 04^{\prime}$ 08,0"), Hilir (S $00^{\circ} 51^{\prime} 21,6$ " dan E $134^{\circ} 04^{\prime} 08,0$ "), Stasiun II: Hulu (S $00^{\circ} 50^{\prime} 02,9$ ' dan E 134 03 ' $\left.40,7^{\prime \prime}\right)$, Hilir (00 $01^{\prime}$ ' 28,9" dan E $134^{0} 03$ ' 59,4”), Stasiun III: Hulu (S 00 051 '52,8" dan E $134^{\circ} 03^{\prime} 54,2^{\prime \prime}$ ), Hilir (S 00 $050^{\prime} 37,5^{\prime \prime}$ dan E $\left.134^{\circ} 03^{\prime} 14,2^{\prime \prime}\right)$.

\section{Alat dan Bahan}

Bahan yang dipergunakan untuk pe-nelitian adalah es batu untuk mengawetkan sampel air. Alat-alat yang digunakan dapat dilihat pada Tabel 1.

Tabel 1. Peralatan yang digunakan

\begin{tabular}{|c|c|}
\hline \multicolumn{2}{|r|}{ Peralatan yang digunakan } \\
\hline Lapangan & Kegunaannya \\
\hline Alat tulis menulis & Mencatat data hasil pengukuran lapangan \\
\hline Papan Lapangan & $\begin{array}{l}\text { Sebagai pengalas buku atau kertas sewaktu menulis data } \\
\text { lapangan }\end{array}$ \\
\hline $\mathrm{pH}$ Meter & Mengukur kadar asam basa perairan. \\
\hline Termometer & Mengukur suhu perairan. \\
\hline Kamera digital & Dokumentasi kegiatan selama penelitian. \\
\hline GPS & Mengambil titik koordinat stasiun pengamatan \\
\hline Botol sampel $100 \mathrm{ml}$ & Wadah tampung air uji dari lapangan. \\
\hline Cool box & Menyimpan sampel. \\
\hline BOD meter & Mengukur BOD \\
\hline TDS meter & Mengukur TDS \\
\hline Air Akuades & Digunakan untuk kalibrasi alat. \\
\hline Tisue & Digunakan untuk pengering alat. \\
\hline \multicolumn{2}{|l|}{ Laboratorium } \\
\hline Gravimetrik & Mengukur TDS dan TSS. \\
\hline Spektrofometer & Mengukur nitrat fosfat dan amonia. \\
\hline Turbitymeter & Untuk mengukur kekeruhan. \\
\hline Pipet & Digunakan untuk titrasi atau pencampuran larutan. \\
\hline Gelas ukur $50 \mathrm{ml}$ & Pengukuran dan pencampuran larutan uji. \\
\hline Vakum & Alat penyedot air pada alat gravimetri. \\
\hline Cawan Porselin & Wadah tampung air uji. \\
\hline Timbangan Analitik & Untuk menimbang kertas saring \\
\hline Hot Plate & Pemanas air \\
\hline Inkubator & Alat sterilisasi \\
\hline Air Akuades & Digunakan untuk kalibrasi. \\
\hline Tisue & Pengering alat. \\
\hline Oven & Pengering sampel. \\
\hline
\end{tabular}


Tabel 2. Parameter, alat dan metode analisis fisika-kimia.

\begin{tabular}{|c|c|c|c|c|}
\hline No. & Parameter & Satuan & $\begin{array}{c}\text { Alat/Metode } \\
\text { Analisis }\end{array}$ & Keterangan \\
\hline \multicolumn{5}{|c|}{ Fisika } \\
\hline 1. & Suhu & ${ }^{\circ} \mathrm{C}$ & Termometer & In situ \\
\hline 2. & TDS & $\mathrm{Mg} / \mathrm{l}$ & Gravimetrik & Laboratorium \\
\hline 3. & TSS & $\mathrm{Mg} / \mathrm{l}$ & Gravimetrik & Laboratorium \\
\hline \multicolumn{5}{|c|}{ Kimia } \\
\hline 1. & $\mathrm{pH}$ & Unit & $\mathrm{pH}$ meter & In situ \\
\hline 2. & DO & $\mathrm{mg} / \mathrm{l}$ & DO meter & In situ \\
\hline 3. & COD & $\mathrm{mg} / \mathrm{l}$ & Titrimetrik & Laboratorium \\
\hline 4. & BOD & $\mathrm{mg} / \mathrm{l}$ & BOD meter & In situ \\
\hline 5. & Nitrat (NO3) & $\mathrm{mg} / \mathrm{l}$ & Spektrofotometrik & Laboratorium \\
\hline 6. & Fosfat (PO4) & $\mathrm{mg} / \mathrm{l}$ & Spektrofotometrik & Laboratorium \\
\hline 7. & Amonia & $\mathrm{mg} / \mathrm{l}$ & Spektrofotometrik & Laboratorium \\
\hline
\end{tabular}

\section{Metode Pengambilan Data}

\section{Parameter Fisika dan Kimia Sungai}

Data parameter fisika dan kimia diperoleh dari pengambilan contoh air Sungai pada tiga stasiun (lokasi). Stasiun I berada pada sungai Momo yang terdiri dari titik sam-pling I berada pada hulu dan titik sampling II berada pada daerah hilir. Stasiun II Yaitu Sungai Sahara yang terdiri dari titik sampling III yang terletak di hulu dan titik sampling IV terletak pada hilir. Sedangkan stasiun III yaitu Sungai konto yang terdiri da-ri titik sampling $\mathrm{V}$ yang terletak di hulu dan titik sampling VI yang terdapat di hilir DAS. Pengambilan contoh air yang dianalisis dila-kukan sesuai dengan titik titik sampling yang telah ditetapkan dari badan sungai dan dila-kukan secara komposit sebanyak dua ulangan dengan interval waktu satu bulan (Tabel 2).

\section{Prosedur Kerja}

Untuk mengetahui beberapa parameter yang diukur, maka kita perlu melakukan uji di laboratorium prosedur pengamatan beberapa parameter yang diukur adalah sebagai berikut:

\section{TDS (Padatan terlarut) dan TSS ( Pada- tan tersuspensi)}

Bahan yang diperlukan dalam menghitung padatan terlarut dan padatan tersus- pensi, adalah sampel air. Prosedur kerjanya sebagai berikut (Santika, 2000):

1. Siapkan Gravimetri dalam kondisi siap dipakai dan pastikan vakum penyedot ter-hubung baik dengan gravimetri.

2. Timbang kertas saring yang akan dipakai, kemudian ambil samper air sebanyak $50 \mathrm{ml}$.

3. Pasang kertas saring pada alat Gravimetri, setelah itu masukkan air dan tekan tombol power.

4. Setelah itu angkat kertas saring dengan pinset lalu masukan kertas saring pada o-ven dengan suhu $105^{\circ} \mathrm{C} \pm 1 \mathrm{jam}$.

5. Kertas saring yang telah melalui proses pengeringan di inkubasi dalam inkubator selama 30 - 60 menit dan setelah itu ditimbang.

Kandungan TDS dapat dihitung dengan rumus :

$\mathrm{TDS}=\frac{(\text { Berat cawan akhir-berat cawan awal) }}{\text { Volume sampel }} \times 1000$

6. Timbang cawan porselin awal.

7. Air yang telah disaring dimasukkan pada cawan porselin yang telah ditimbang untuk kemudian dipanaskan.

8. Panaskan cawan porselin yang berisi air saringan hingga airnya habis.

9. Setelah air dalam cawan habis, masukkan cawan tersebut dalam inkubator 30-60 menit dan setelah itu ditimbang. 
10.Kandungan TSS dapat dihitung dengan rumus :

$\mathrm{TSS}=\frac{(\text { Berat kertas saring akhir-berat kertas saring awal) }}{\text { Volume sampel }} \times 1000$

\section{Fosfat}

Bahan yang diperlukan untuk melihat nilai $\mathrm{m}$ fosfat yang berada dalam sampel, adalah sampel air. Prosedur kerjanya sebagai berikut (Santika, 2000):

1. Nyalakan CCD Reaktor dengan panas $150^{\circ} \mathrm{C}$.

2. Gunakan pipet untuk menambah $5 \mathrm{ml}$ sampel pada vial yang telah terisi asam lydrolyzable.

3. Tambahkan satu bungkus potasium persulfate untuk fosfat pada vial.

4. Tutup dan aduk sampai larut.

5. Masukkan vial pada CCD Reaktor selama 30 menit, setelah itu pindahkan vial terse-but ke rak tabung reaksi dan dinginkan pada suhu ruang.

6. Setelah dingin, pipet $2 \mathrm{ml}$, larutkan standar sodium hidroksida $1,54 \mathrm{~N}$ kedalam vial. Tutup dan aduk.

7. Lap bagian luar vial dengan tisue untuk menghilangkan sidik jari dan tanda lain-nya.

8. Ukur sebagai blanko, tekan zero.

9. Setelah itu tambahkan i bubuk phosvat 3 kedalam vial. Tutup dan aduk sampai ter-campur 10-15 detik. (bubuk tersebut tidak mungkin tercampur sempurna).

10.Diamkan selama 2 menit. Baca sampel selama 2-8 menit setelah waktu habis, sete-lah waktu habis lap bagian luar vial dengan tisue untuk menghapus sidik jari dan tanda lainnya yang dapat atau akan mengganggu pembacaan pada spektro.
11.Masukkan vial ke dalam spektro dan ukur. (tekan read).

\section{Amonia dan Nitrat}

Bahan yang diperlukan untuk melihat nilai Amonia dan Nitrat yang berada dalam sampel, adalah sampel air. Prosedur kerjanya sebagai berikut (Santika, 2000):

1. Ukur $10 \mathrm{ml}$ sampel lalu masukan dalam vial.

2. Ukur $10 \mathrm{ml}$ akuadest lalu masukkan dalam vial yang berbeda.

3. Tambahkann masing-masing 1 bungkus (amonia salisilat untuk uji amonia dan nitrit untuk uji nitrit salisilat) kedalam vial tutup dan aduk sampai larut. Diamkan selama 3 menit.

4. Setelah 3 tambahkan masing-masing 1 bungkus bubuk (amonia cyanurate untuk uji amonia dan nitrit untuk uji nitrit cya-nurate) kedalam vial, tutup dan aduk sampai regent larut.

5. Diamkan selama 15 menit, warna hijau akan muncul bila amonia atau nitrit ada di dalamnya.

6. Masukkan blanko, tekan zero kemudian masukkan sampel dan tekan read.

\section{Analisis}

Hasil pengukuran di laboratorium yang diperoleh pada setiap stasiun, selanjutnya di-bandingkan dengan baku mutu kulitas air me-nurut standar baku mutu Peraturan Pemerintah Nomor 82 Tahun 2001 tentang pengelolaan kualitas air dan pengendalian pencemaran guna menentukan status mutu kualitas air sungai dari ketiga lokasi penelitian. Tabel 3.

Tabel 3. Standar Baku Mutu menurut PP Nomor 82 Tahun 2001 tentang pengelolaan Kualitas Air dan Pengendalian Pencemaran Air

\begin{tabular}{lccccc}
\hline \multirow{2}{*}{ Parameter } & \multirow{2}{*}{ Satuan } & \multicolumn{5}{c}{ Standar Baku Mutu } \\
\cline { 3 - 6 } & & $\mathrm{I}$ & $\mathrm{II}$ & $\mathrm{III}$ & IV \\
\hline pH & & $6-9$ & $6-9$ & $6-9$ & $5-9$ \\
DO & $\mathrm{Mg} / 1$ & 6 & 4 & 3 & 0 \\
COD & $\mathrm{Mg} / 1$ & 10 & 25 & 50 & 100 \\
BOD & $\mathrm{Mg} / 1$ & 2 & 3 & 6 & 12 \\
Nitrat & $\mathrm{Mg} / 1$ & 10 & 10 & 20 & 20 \\
Fosfat & $\mathrm{Mg} / 1$ & 0,2 & 0,2 & 1 & 5 \\
\hline
\end{tabular}




\begin{tabular}{lccccc}
\hline Amonia & $\mathrm{Mg} / \mathrm{l}$ & 0,5 & - & - & - \\
TDS & $\mathrm{Mg} / \mathrm{l}$ & 1000 & 1000 & 1000 & 2000 \\
TSS & $\mathrm{Mg} / 1$ & 50 & 50 & 400 & 400 \\
\hline
\end{tabular}

\section{HASIL DAN PEMBAHASAN}

\section{Kualitas Fisik Perairan}

Suhu air rata-rata pada ketiga stasiun berkisar antara $26,6-31^{\circ} \mathrm{C}(\mathrm{Gam}-$ bar 2) masih tergolong normal dalam badan air dan tidak membahayakan kehidupan biota akuatik karena masih di bawah lethal temperature bagi organisme bentik dengan kisaran $35-40^{\circ} \mathrm{C}$ (Welch, 1980 dalam Widiastuty, 2001). Pengukuran kekeruhan pada tiga stasiun selama penelitian menghasilkan berkisar 0,1749,7 NTU (Gambar 3). Peningkatan kekeruhan ini disebabkan adanya masukan padatan total berupa bahan organik maupun partikel tanah yang tidak segera mengendap. Nilai kekeruhan limbah yang lebih tinggi dari kekeruhan perairan di hilir yaitu 33,6 NTU.

Tingginya konsentrasi TDS di stasiun $1(>3,00 \mathrm{mg} / \mathrm{l})$ ada daerah hilir diduga disebabkan oleh masukan limbah cair pabrik tahu yang mengandung padatan terlarut dengan konsentrasi cukup tinggi, sehingga meningkatkan konsentrasi TDS di perairan Sungai Momo (Gambar 4). Dugaan tersebut diperkuat oleh saluran pembuangan pabrik tahu langsung ke sungai tanpa adanya bak penampungan limbah. Rendahnya konsentrasi TDS di stasiun 2 dan 3 diduga karena masukan berupa padatan total didominasi oleh padatan tersuspensi. Penggunaan lahan dari hulu dan sepanjang aliran sungai sampai hilir sebagian besar merupakan perumahan dan ada beberapa perkebunan, sehingga dimungkinkan terjadinya erosi partikel tanah berukuran suspensi yang kemudian masuk ke sungai. Konsentrasi rata-rata TSS tertinggi (Gambar 5) berada pada daerah hilir ke tiga stasiun pengamatan. Penggunaan lahan dari hulu dan sepanjang aliran Sungai sampai hilir sebagian besar merupakan daerah pemukiman dan ada beberapa tempat yang digunakan sebagai daerah pertanian. Jenis penggunaan lahan ini memungkinkan terjadinya erosi partikel tanah berukuran suspensi yang kemudian masuk ke sungai dan meningkatkan konsentrasi padatan tarsuspensi dalam air sungai.

\section{Kualitas Kimiawi Perairan}

Pengukuran $\mathrm{pH}$ air berkisar 6-8, dan untuk stasiun 1 diduga karena besarnya kan-dungan bahan organik pada limbah yang berasal dari pemukiman di hulu dan sepanjang aliran sungai, sehingga dalam proses penguraiannya oleh mikroorganisme maupun terjadinya pembusukan, tetapi masih dalam batas normal. Kandungan DO pada tiga stasiun yaitu $0,03-$ $6,22 \mathrm{mg} / \mathrm{l}$. Konsentrasi rata-rata DO tertinggi terdapat pada daerah hulu sungai masing-masing stasiun dan terendah pada daerah hilir. Rendahnya kisaran DO tersebut merupakan indikasi kuat telah terjadi pencemaran yang diduga disebabkan limbah pemukiman dan berpotensi menyebabkan pencemaran. Iskandar (1995) menyatakan bahwa limbah industri pakan dan pemukiman sering menimbulkan masalah pencemaran perairan karena BOD yang tinggi serta rendahnya kandungan oksigen terlarut. Khusus untuk limbah pakan mengalami penguraian menjadi bahan beracun, seperti $\mathrm{H}_{2} \mathrm{~S}$, ammonia dan nitrit, sehingga akibat dari buangan organik dalam jumlah yang berlebihan adalah penurunan kandungan oksigen terlarut dalam air. 


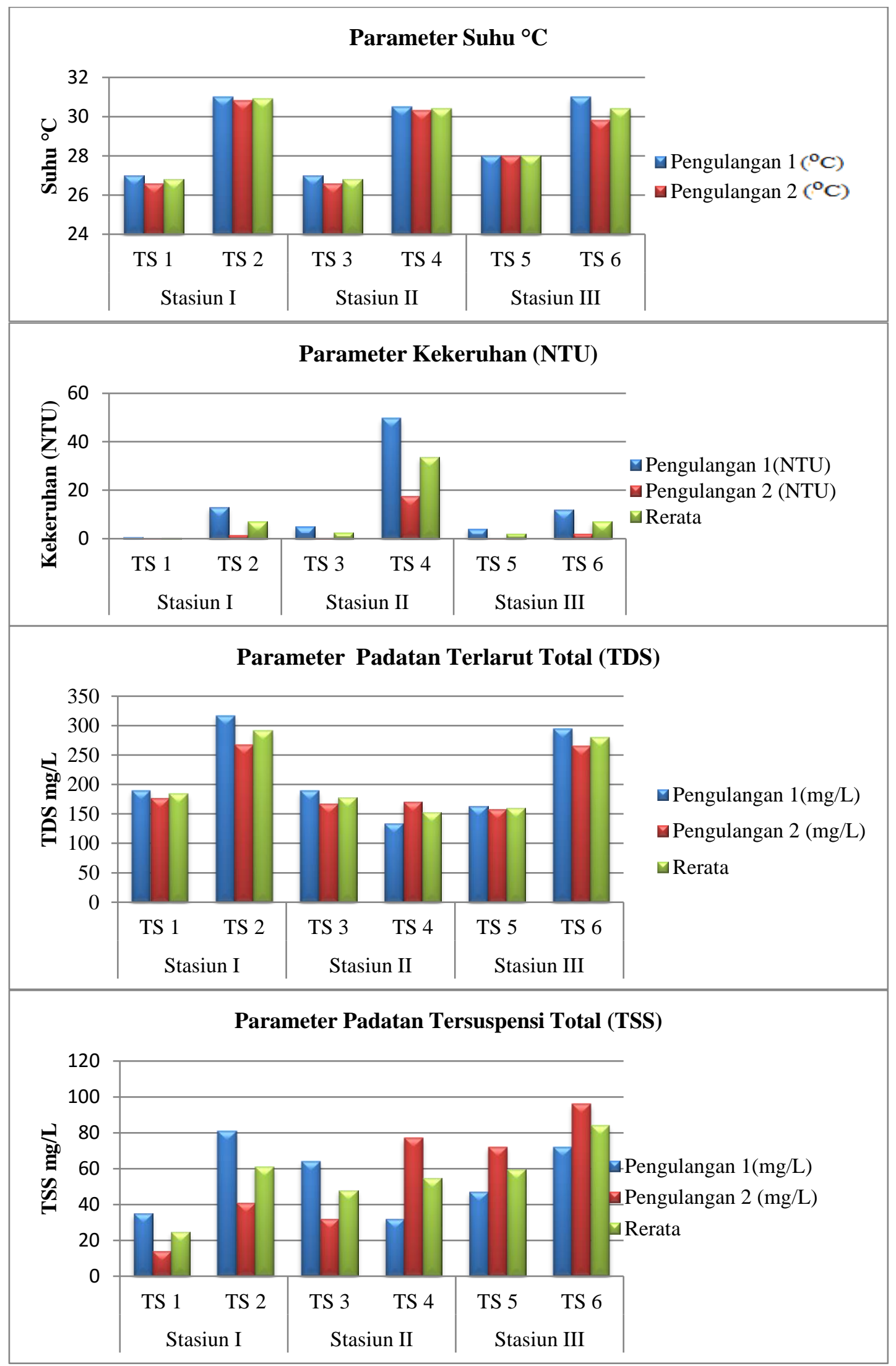

Gambar 2. Grafik parameter suhu, kekeruhan, TDS dan TSS 
Hasil pengukuran COD seluruh stasiun menunjukkan kisaran $<4,99$ $27,75 \mathrm{mg} / \mathrm{l}$. Nilai COD tertinggi terdapat pada stasiun 1 dan stasiun 3 pada bagian hilir. Penurunan COD pada stasiun 2 juga dapat terjadi karena bahan organik pada perairan ini telah mengalami penguraian , sehingga pada stasiun 2 konsentrasinya telah berkurang. Sedangkan BOD pada stasiun 1 cukup tinggi diduga karena pengaruh serasah daun yang terletak di hulu sungai dan sepanjang aliran sungai. Penurunan nilai rata-rata BOD yang cukup besar, mencapai 5,09 mg/l, terjadi pada stasiun 1 walaupun stasiun ini merupakan bagian aliran sungai sesaat setelah mendapat masukan limbah pertanian yaitu serasah daun. Kecenderungan penurunan BOD pada stasiun 1 diduga merupakan efek pengenceran dari limbah cair pabrik tahu, dimana sebagian besar komponennya berupa air.

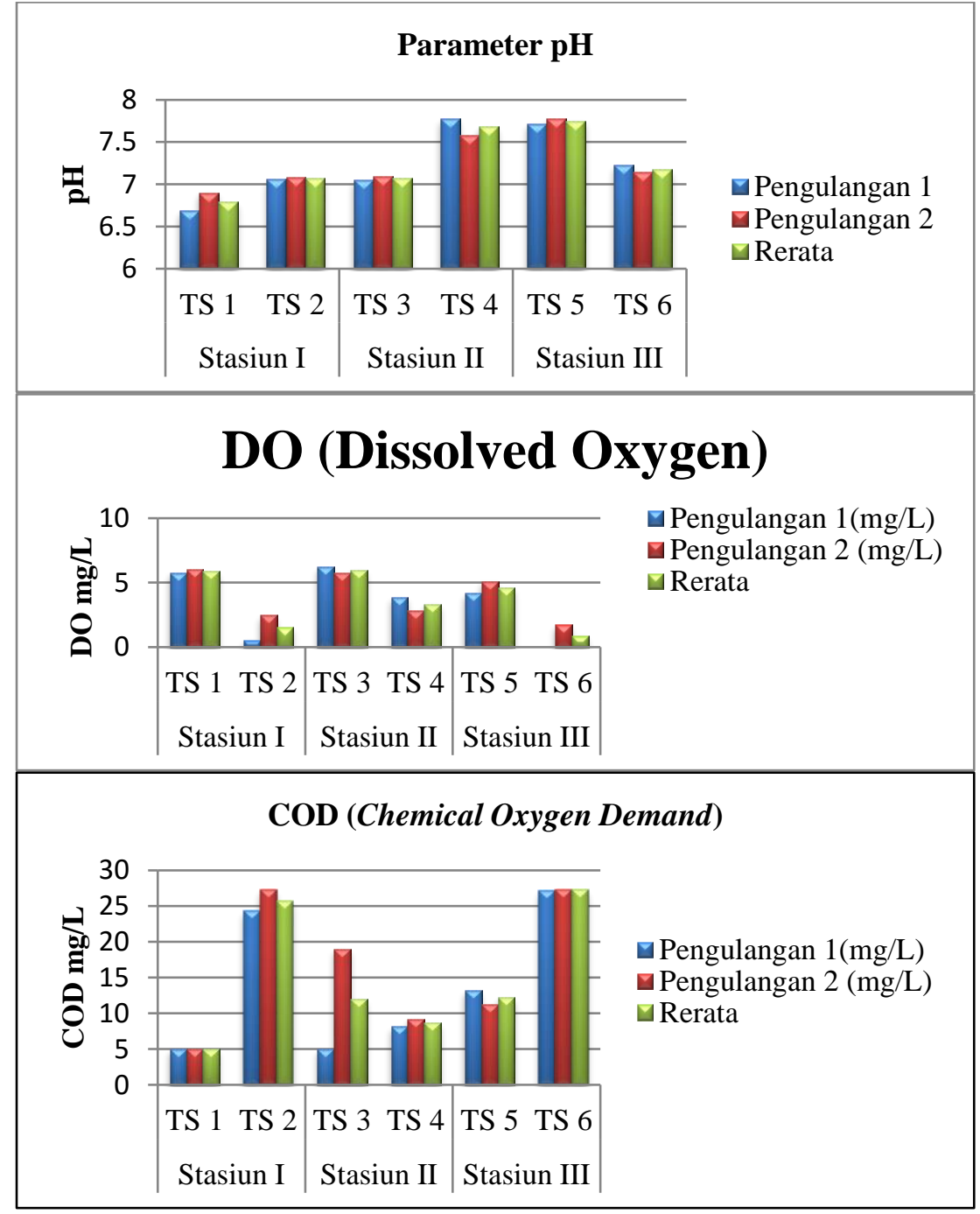

Gambar 3. Parameter pH, DO, dan COD 


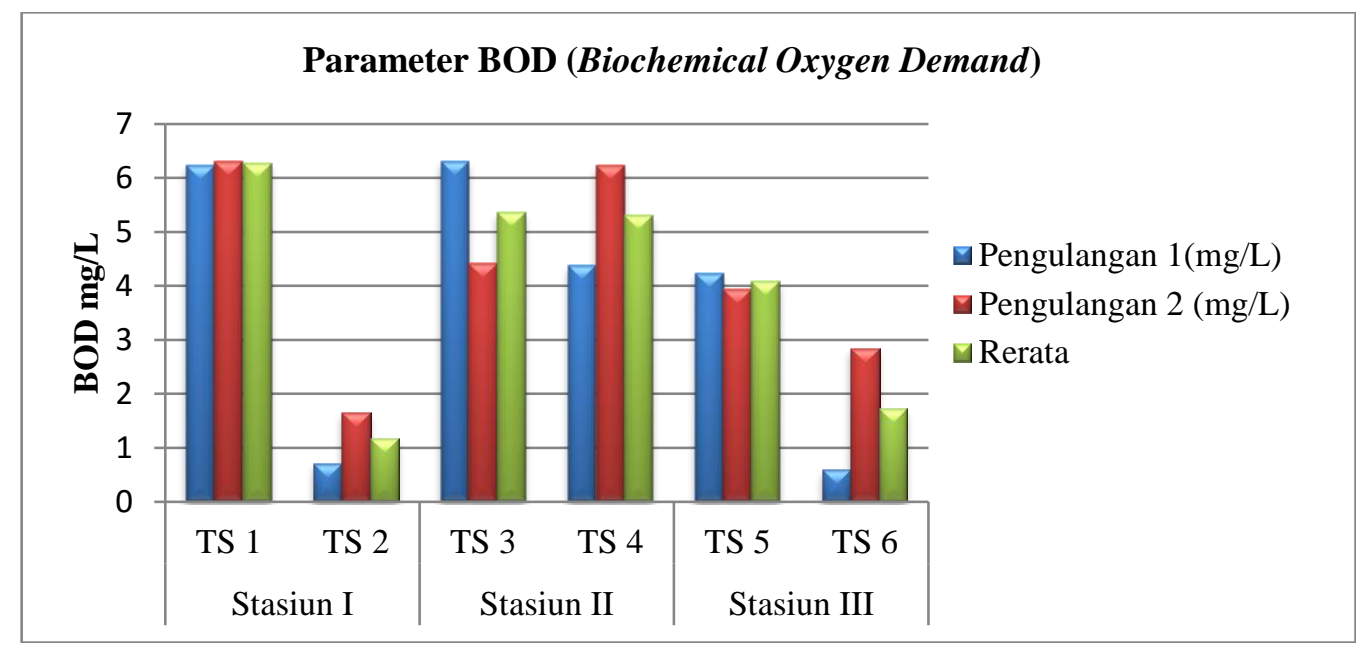

Gambar 4. Parameter BOD

Kandungan nitrat tertinggi terdapat pada stasiun 2 yang diduga disebabkan adanya masukan limbah yang mengandung nitrat dari limbah pemukiman dan pertanian. Peningkatan kadar nitrat mengindikasikan efisiensi dalam pembenahan air limbah (Mahida, 1984). Namun, bila nitrat di perairan terdapat dalam konsentrasi tinggi akan merangsang partumbuhan ganggang yang tak terbatas sehingga air kekurangan oksigen terlarut dan mengakibatkan kematian bagi organisme akuatik yang tidak tahan dengan kondisi DO rendah (Alaerts danSantika, 1984 dalam Mirna, 2005). Limbah organik berpotensi besar dalam meningkatkan konsentrasi nitrat di perairan.

Kadar fosfat pada stasiun 1 dan 2 hanya berkisar antara 0,013 dan 0,044 $\mathrm{mg} / \mathrm{L}$ rendahnya fosfat pada stasiun ini biasanya disebabkan fosfat mengalami pengenda-pan bersama partikel lumpur sehingga unsur tersebut menghilang dari badan air (Welch, 1980 dalam Mayani, 2000). Rendahnya fosfat juga diduga terjadi karena adanya pemanfaatan fosfat oleh organisme akuatik seperti fitoplankton. Rata-rata nilai tertinggi terdapat pada stasiun 2 dan 1, hal ini di duga karena buangan limbah pemukiman, peternakan dan erosi tanah yang cukup besar. Pada stasiun 3 relatif lebih kecil di banding stasiun 2 dan 1. Kadar amonia pada perairan biasanya kurang dari $0,1 \mathrm{mg} / \mathrm{l}(\mathrm{Mc}$ Neely dkk. 1979 dalam Mirna, 2005).
Kadar amonia bebas yang tidak terionisasi (NH3) pada perairan tawar sebaiknya tidak lebih dari $0,2 \mathrm{mg} / \mathrm{l}$. Jika kadar amonia bebas lebih dari $0,2 \mathrm{mg} / \mathrm{l}$, perairan bersifat toksik bagi beberapa jenis biota (Sawyer dan Mc Carty, 1978 dalam Mirna, 2005).

Pengaruh limbah organik terhadap konsentrasi nitrat di sunagi kecil yang bermuara di Teluk Sawaibu juga dapat dilihat pada stasiun 1 dan 3 pada daerah hilir dimana kandungan nitrat juga telah me-lebihi konsentrasi pada perairan alami. Tingginya kandungan nitrat pada stasiun 1 dan 3 diduga karena pengaruh limbah organik dari pemukiman di hulu dan sepanjang Sungai sampai hilir. Seperti yang dikemukakan Welch (1980) dalam Mayani (2000), pada umumnya fitoplankton memanfaatkan nitrogen anorganik seperti nitrat $\left(\mathrm{NO}_{3}-\mathrm{N}\right)$ dan ammonia $\left(\mathrm{NH}_{3}-\mathrm{N}\right)$. 


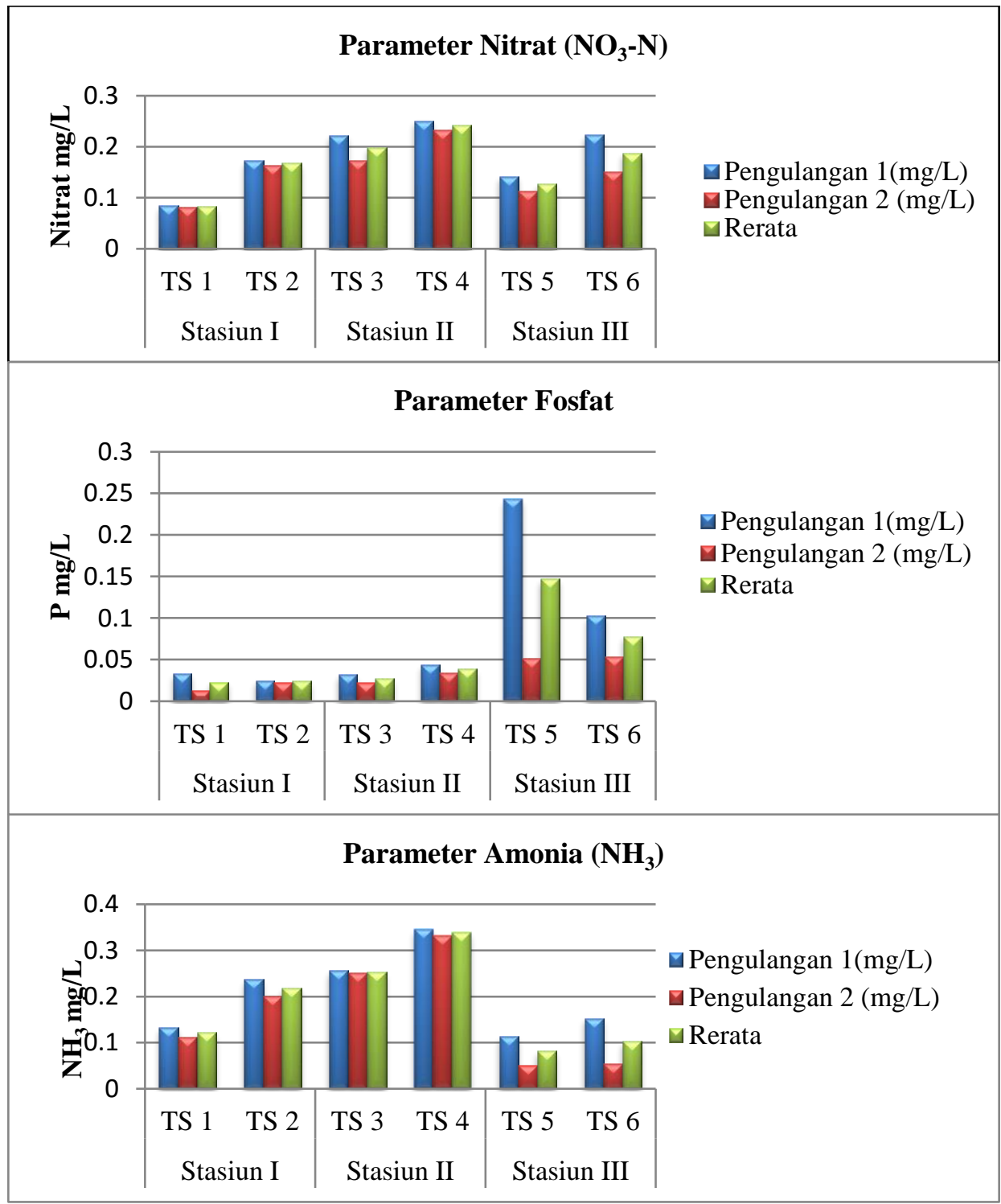

Gambar 5. Grafik Parameter Amonia

\section{KESIMPULAN}

Kualitas air pada ketiga sungai kecil (Momo, Sahara, Konto) yang bermuara di Teluk Sawaibu Kabupaten Manokwari telah melewati persyaratan baku mutu kualitas air berdasarkan Peraturan Pemerintah nomor 82 tahun 2001 tentang pengelolaan kualitas air dan pengendalian pencemaran air. Kisaran suhu dari tiga stasiun pengamatan berkisar antara 26,6 $31^{\circ} \mathrm{C}$, kekeruhan berkisar $0,17-49,7$ NTU. Padatan Terlarut Total (TDS) 134 - 317 mg/l. Padatan Tersuspensi Total $14-96$ $\mathrm{mg} / \mathrm{l}$. pH berkisar antara 6,69-7,78. DO (Dissolved Oxygen) 0,03-6,22 mg/l. COD (Chemical Oxygen Demand) <4,99 -
27,75 mg/l, BOD (Biochemical Oxygen Demand) 0,60 - 6,31 mg/l, Nitrat $\left(\mathrm{NO}_{3}\right.$ N) $0,013-0,251 \mathrm{mg} / \mathrm{l}$, Fosfat $\left(\mathrm{PO}_{4}\right) 0,013$ - 0,243 mg/l dan Amonia $\left(\mathrm{NH}_{3}\right)$ 0,051 $0,346 \mathrm{mg} / \mathrm{l}$.

\section{DAFTAR PUSTAKA}

Badan Pusat Statistika Kabupaten Manokwari. 2013. Kabupaten Manokwari Dalam Angka. Manokwari Tahun 2013 : BPS Kabupaten Manokwari.

Iskandar. 1995. Struktur Komunitas makrozoobentos di Kawasan Pandu Tambak Inti Rakyat Karawang 
Jawa Barat. Tesis. Program Pascasarjana. IPB. Bogor.

Kantor Menteri Negara KLH. 1988. Pedoman Baku Mutu Lingkungan. Nomor Kep-02/MENKLH/I/1988. Sekretariat Menteri Negara Kependudukan dan Lingkungan Hidup. Jakarta.

Mahida, U. N. 1984. Pencemaran Air dan Pemanfaatan Limbah Industri. Rajawali Press. Jakarta.

Mayani, I. 2000. Kesuburan Perairan Berdasarkan Kandungan Unsur Hara dan P serta Struktur Komunitas Fitoplankton di Situ Citayam, Bojong Gede, Bogor, Jawa Barat. Skripsi. Program Manajemen Sumberdaya Perairan. Fakultas Perikanan dan Ilmu Kelautan. IPB. Bogor.

Mirna, A.P. 2005. Evaluasi Kualitas Air Sungai Way Sulan Kecil Kabupaten Lampung Selatan. Skripsi. Departemen Konservasi Sumberdaya Hutan Dan Ekowisata Fakultas Kehutanan Institut Pertanian Bogor.

Peraturan Pemerintah Republik Indonesia Nomor 82 Tahun 2001 Tentang Pengelolaan kualitas Air dan Pengendalian Pencemaran Air.

Peraturan Pemerintah Nomor 20 Tahun 1990 Tentang Pengendalian Pencemaran Air dan Lingkungan.

Suin, M. N. 1994. Dampak Pencemaran pada Ekosistem Perairan. Proseeding Penataran Pencemaran Lingkungan, Dampak dan Penanggulangannya. Padang. Program Pascasarjana. IPB. Bogor.

Undang-undang Republik Indonesia Nomor 23 Tahun 1997 Tentang Pengelolaan Lingkungan Hidup.

Widiastuty, S. 2001. Dampak Pengelolaan Limbah Cair PT Pupuk Sriwidjaja Terhadap Kualitas Air Sungai Musi Kotamadya Palembang. Tesis. Program Pascasarjana. IPB. Bogor.

Zairion, D. 2003. Dampak Pembangunan Terhadap Biota Air. Makalah Kursus AMDAL, IPB. Bogor. 
